\title{
Importance of Underutilized Crops in Thanamalwila Divisional Secretariat Division in Monaragala District in Sri Lanka
}

\author{
S.H.P. Malkanthi ${ }^{1}$ \\ Received: $21^{\text {st }}$ September 2016 / Accepted: 13 $3^{\text {th }}$ February 2017
}

\begin{abstract}
Underutilized crops serve many purposes for a household. This study was conducted to study the importance of these crops for households in Thanamalwila divisional secretariat division in Moneragala District. The purpose of this research was to identify the importance of underutilized crops for farmers in Monaragala District of Sri Lanka. Data were collected from 120 farmers who cultivate underutilized crops, through a field survey with the help of a questionnaire during January-October 2015. Group discussions were also conducted to collect in-depth information. The findings reveal, a significant number of underutilized crop species are being cultivated by the farmers. Among them, some cereals, vegetables, legumes, fruits, yams and tuber crops and herbals are common. Farmers' main goals of cultivation are to fulfill the food requirement of the family, find extra income and to use them as herbals for simple health disorders. When farmers' attitudes towards the underutilized crops are taken into consideration, they have positive attitude towards economic benefits of cultivating underutilized crops, medicinal and nutritional values, low cost of cultivation, less water requirements, less pest and disease problems, etc. However, farmers have neither agreed nor disagreed upon three broad levels of importance of underutilized crops namely, contributing to the biodiversity, environmental protection and tolerance to climate changes. Most of the farmers have general understanding about the importance of underutilized crops. Moreover, farmers are still willing to cultivate these crops for selling if they can have necessary facilities and a good market.
\end{abstract}

Keywords: Underutilized crops, food security, extra income, medicinal values, Moneragala

\section{INTRODUCTION}

Underutilized or neglected crop species are often indigenous ancient crop species which are still used at low levels within the local, national and even international communities, but have the potential to contribute further to the food supply than they currently do (Mayes et al., 2011). Moreover as per the strategic framework for research and development of underutilized plant species developed by International Centre for Underutilized Crops (ICUC), and a range of stakeholders, underutilized plant species (UPS) are defined as "Species with under-exploited potential for contribution to food security, health, income generation and environmental services". The benefits of these species are manifold as these crops contribute to household livelihoods, poverty alleviation through providing new market opportunities for value added products, food security and nutrition maintaining (Hoeschle-Zeledon and Bordoni, 2003; Taylor et al., 2009). However, the role of underutilized crops is often ignored or underestimated.

Sri Lanka is one of the countries which highly depend on agriculture since the early days. Although the method of farming and varieties of crops cultivating have changed, yet most of the people in the entire country do farming either as their main income generating or part 
time extra income generating occupation. At present, the demand for modern commercialized crop varieties has increased. Hence, cultivation of modern commercialized crop varieties has increased and most of the traditional varieties remain as underutilized crops. However, recently, some underutilized crops have been identified for commercialization by the ICUC. The ICUC has trained locals in food processing with underutilized crops and gives support to commercialize these underutilized crops such as Jack fruit (Artocarpus heterophyllus), Beli (Aegle marmelos), Anoda (Annona muricata).

Cultivation of underutilized crops has decreased due to the failure in competing with the commercial crops that have dominated the modern world and supported by seed supply systems (Chivenge et al, 2015). Production, post-harvest technologies and extension services for underutilized crops are in dire conditions compared to modern commercialized crops. In addition, there is no established proper market and most of the consumers are not accustomed of using them.

Underutilized crops are found in numerous agricultural ecosystems and often survive mainly in marginal areas (Williams and Haq, 2010). There are several underutilized and newly-introduced plant species that have been naturalized well in the country. These species have held great potential to be exploited for various purposes. Among them several categories of underutilized crops were specially focused under this study which includes Cereals: Finger millet (Eleusine coracana), Heen Meneri (Panicum sumatrense) and Thana hal (Setaria italica); Vegetables: Kekiri (Cucumis sativus), Thibbatu (Solanum torvum), Bitter gourd (Momordica charantia L.); Leafy vegetables: Thampala (Amaranthus tricolor amaranth), Sarana (Boerhavia diffusa) Thebu (Costus speciosus) and Kirihenda (Celosia argentea); Legumes: Black gram (Vigna mungo (L.));Oil crops: Gingili (Sesamum indicum), Mustard (Brassica juncea); Root and Tuber crops:
Kiriala (Dioscorea alata), Gahala (Colocasia esculenta); Fruit crops: Anoda (Annona muricata), Jambu (Syzygium jambos), Lawulu (Pouteria campechiana) and etc.; Herbal crops: Ginjer (Zingiber officinale), Endaru (Ricinus communis) and etc.(Table 01).

Sri Lankan people in the past had used various crop varieties to fulfill their food requirements. However, nowadays these crops have displaced or underutilized due to several reasons. Among them, lack of awareness among farmers on importance of these crops is one of the main reasons. Therefore, the main aim of this study was to find out the importance of underutilized crops from farmers' point of view and also to find out the attitudes of farmers towards underutilized crops.

\section{Importance of underutilized crops}

The underutilized crops are species that are used traditionally in the past for food, fibers, fodder, oil or medicinal properties. They have an under exploited potential to contribute to food security, nutrition, health, income generation and environmental services (Hoeschle et al., 2009). The huge numbers of those underutilized species represent a massive unused commodity resource which can help to meet the increasing demand for food, energy, medicines and industrial desires (Malkanthi et al., 2014).Some of these unused assets are either partly or fully domesticated but most stay wild and unevaluated. With the development of modern agricultural practices, the potential of many of these commodity resources have been neglected. Some have been severely neglected and the erosion of their gene pools has seemed to be severe that they are often regarded as "lost crops". Nevertheless, much of the world's underutilized crops and commodities play a vital role in the lives of the rural poor, because they contribute to better livelihoods by poverty alleviation and sustaining the environment. Many of these species were included in traditional subsistence farming systems 
particularly in marginal areas and in many cases, these crops and commodities are lifesavers for millions of resource-poor people in regions where food and nutritional security are significant problems (Williams and Haq, 2010).

According to Taylor et al.,(2009), neglected and underutilized crops also represent an important source of revenue for local economies and are part of the rich, cultural and traditional heritage of communities around the world. As compared to the major crops, they require relatively low inputs and therefore, contribute to sustainable agricultural production. Underutilized species are highly beneficial and valuable as they provide a unique opportunity to both combating food and nutritional insecurity within communities and at the same time, supporting the development of niche markets for global trade. Chandrarathne (2007) mentioned the advantages of underutilized crops such as alleviation of poverty by enhancing nutritional quality and safety, increasing income from fruit and vegetables and sustainable income generation from forest and trees.

Neglected or underutilized crops have the potential to play a number of roles in the improvement of food security that include: part of a focused effort to help the poor for subsistence and income, the majority of whom live in the Southern part of the world; a way to reduce the risk of over-reliance on very limited numbers of major crops; a way to increase sustainability of agriculture through a reduction in inputs, such as fossil fuel-derived nitrogen fertilizers and fuel for agriculture, given the risks of the carbon footprint of agriculture on climate change and the transition to a post peak-oil world; a contribution to food quality; and a way to preserve and celebrate cultural and dietary diversity (Mayes et al., 2011).

There is an increasing endorsement at national and international level of the important role in sustainable farming systems and human wellbeing of less-used crops and species. According to Padulosi et al., (1999) underutilized crops are important for environmental changes and ecosystem stability, Food security and nutrition, increased attention to indigenous knowledge. And furthermore Padulosi et al., (1999) said that many underutilized species have multiple uses and do not belong to any one specific category of crops (food, medicinal, ornamental, etc.). The key to unlock their true potential rests in our ability to harness their multiple uses, and traditional, single-use enhancement approaches are not the best way to achieve their full valorization.

Hence, the production of underutilized crops plays a central role in ensuring the food security for millions of people worldwide (Williams and Haq, 2010). The benefits of these species are many fold: They have potential to contribute to poverty elimination through employment opportunities and income generation and also through improved efficiency and profitability of farm household labor use in both rural and urban environments. They can contribute to sustainable livelihoods through household food security as they can widen the food basket. They add nutrients to the diet and are sometimes convenient food for low income urban people. They are adapted to fragile environments and can contribute to the stability of agroecosystems, particularly in the arid, semi-arid lands, mountains, steppes and tropical forests. They provide a broad portfolio of crops to improve productivity and global food security and to meet new market demands. They assist development through small-scale investment. They have a strong cultural identity and are associated with traditional customs and beliefs (Williams and Haq, 2000).

Moreover, many neglected and underutilized species are extremely important for food production in low income food deficit countries. They are locally well adapted to marginal lands and constitute an important part of the local diet, providing valuable nutritional elements (e.g. protein, vitamins, and minerals) and spices, often 
lacking in staple crops. Their role in traditional medicine is also well known. Neglected and underutilized crops also represent an important source of revenue for local economies and are part of the rich cultural and traditional heritage of communities around the world. In addition, these crops are important sources of resistance genes for biotic and abiotic stress breeding that can be utilized also for the genetic improvement of commodity crops (Kole, 2011).

The overall objective of this research was to study the importance of underutilized crops for farmers in Monaragala District in Sri Lanka. Specific objectives were to find the present situation of cultivation of underutilized crops in this area and find the major goals of farmers' to cultivate underutilized crops in this area. Furthermore, assessment of farmers' attitude on the importance of selected underutilized crops was also an important objective of the study.

\section{METHODOLOGY}

Uva and Eastern provinces were identified as historically important farming regions with considerable amount of backyard production of underutilized crops (Bandula et al., 2015). Monaragala district was purposely selected for this study since it belongs to the Uva province where many farming regions of underutilized crops could be observed. Then from 11 Divisional Secretariat (DS) Divisions, Thanamalwila DS division was randomly selected for the study. Thereafter, out of 3603 farming families, 120 underutilized crop cultivators were randomly selected for the study. Primary data were collected from those underutilized cultivators with a help of a field survey using pre-tested questionnaire during January-October 2015. Furthermore, few group discussions were also carried out to gather in-depth information on relevant aspects of underutilized crops. The data analysis was done by MS EXCEL software. Descriptive statistics and mean analysis were used to identify several useful aspects on the importance of underutilized crops.

\section{RESULTS AND DISCUSSION}

\section{Main underutilized crops cultivated in Thanamalwila DS division in Monaragala district}

Numerous underutilized crops have being cultivating in the area. Most common underutilized crops were Finger millet (Eleusine coracana), Heen Meneri (Panicum sumatrense) and Thana hal (Setaria italica); Vegetables: Alupuhul (Beninca sahispida), Kekiri (Cucumis sativus), Thibbatu (Solanum torvum), Bitter gourd (Momordica charantia L.), Diyalabu (Lagenaria siceraria), ; Leafy vegetables: Thampala (Amaranthus tricolor amaranth), Sarana (Boerhavia diffusa) Thebu (Costus speciosus) and Kirihenda (Celosia argentea); Legumes: Black gram (Vigna mungo (L.)); Oil crops: Gingili (Sesamum indicum), Mustard (Brassica juncea); Root and Tuber crops: Welala (Colocasia nymplimfolia), Kiri ala (Dioscorea alata), Gahala (Colocasia esculenta), Buthsarana (Canna indica); Fruit crops: Sidaran (Citrus medica), Anoda (Annona muricata), Jambu (Syzygium jambos), Lawulu (Pouteria campechiana), Bilin (Averrhoa bilimbi), Beli (Aegle marmelos), Kamaranga (Averrhoa carambola), Nelli (Phyllanthu sembelica) and etc.; Herbal crops: Ginger (Zingiber officinale), Endaru (Ricinus communis) Welpenela (Cardiospermum halicacabum) and etc (Table 01). Though there are lots of species of underutilized crops in the study area most of the underutilized crops are being cultivated at the small scale level. 
Table 01: Commonly cultivating underutilized crops and number of farmers cultivating these crops

\begin{tabular}{|c|c|c|c|c|}
\hline & \multirow{2}{*}{\multicolumn{2}{|c|}{ Underutilized crop }} & \multicolumn{2}{|c|}{ Number of Farmers } \\
\hline & & & Frequency & Percentage (\%) \\
\hline \multirow{3}{*}{ Cereals } & Finger millet & Eleusine coracana & 106 & 88.3 \\
\hline & Heen meneri & Panicum sumatrense & 106 & 88.3 \\
\hline & Thana hal & Setaria italica & 14 & 11.7 \\
\hline \multirow{3}{*}{ Vegetables } & Kekiri & Cucumis sativus & 06 & 05.0 \\
\hline & Tibbatu & Solanum torvum & 08 & 06.7 \\
\hline & Bitter gourd & Momordica charantia L. & 30 & 25.0 \\
\hline \multirow{4}{*}{$\begin{array}{c}\text { Leafy } \\
\text { vegetables }\end{array}$} & Thampala & Amaranthus tricolor Amaranth & 42 & 35.0 \\
\hline & Sarana & Boerhavia diffusa & 20 & 16.7 \\
\hline & Thebu & Costus speciosus & 02 & 01.7 \\
\hline & Kirihenda & Celosia argentea & 04 & 03.3 \\
\hline \multirow{2}{*}{ Legumes } & Black gram & Vigna mungo (L.) & 14 & 11.7 \\
\hline & Horse gram & Macrotyloma uniflorum & 17 & 14.2 \\
\hline \multirow{2}{*}{ Oil Crops } & Gingili & Sesamum indicum & 70 & 58.3 \\
\hline & Mastard & Brassica juncea & 04 & 03.3 \\
\hline \multirow{3}{*}{$\begin{array}{l}\text { Root and tuber } \\
\text { crops }\end{array}$} & Kiriala & Dioscorea alata & 02 & 01.7 \\
\hline & Gahala & Colocasiae sculenta & 08 & 06.7 \\
\hline & Tamarind & Tamarindus indica & 38 & 31.7 \\
\hline \multirow{7}{*}{ Fruit Crops } & Anoda & Annona muricata & 14 & 11.7 \\
\hline & Jambu & Syzygium jambos & 02 & 01.7 \\
\hline & Lawulu & pouteria campechiana & 08 & 06.7 \\
\hline & Uguressa & Flacourtia indica & 10 & 08.3 \\
\hline & Weralu & Elaeocarpus serratus & 02 & 01.7 \\
\hline & Local Delum & Punica granatum L. & 44 & 36.7 \\
\hline & Local Dodam & Citrus grandis & 36 & 30.0 \\
\hline \multirow{7}{*}{ Herbal crops } & Ginger & Zingiber officinale & 38 & 31.7 \\
\hline & Endaru & Ricinus communis & 20 & 16.7 \\
\hline & Wetahira & Justicia adhatoda & 06 & 05.0 \\
\hline & Nika & Vitex negundo & 06 & 05.0 \\
\hline & Tippili & Piper longum & 02 & 01.7 \\
\hline & Wadakaha & Acorus calamus & 20 & 16.7 \\
\hline & Kohila & Lasia spinosa & 06 & 05.0 \\
\hline
\end{tabular}

\section{Importance of cultivating underutilized crops}

According to the study, three main importance of underutilized crops for farmers were identified. They were.

1. Contribution of underutilized crops for the food requirement of the family.
Underutilized crops' contribution to the food requirement of a family was measured by calculating the number of whole meals such as Finger millet rotti, Finger mille thalapa, Thanahal milk rice, Thanahal forage, boiled Gahala and boiled Kollu with scrapped coconut and also Meneri forage etc made of underutilized crops and consumed by a family in a given 
week. Generally, total food requirement per week is 21 meals ( 3 meals per day and there are 7 days per week). The highest number of families $(63.33 \%)$ has consumed $1-3$ numbers of meals, produced from the underutilized crops (10\% of the food requirement) per week. About $25 \%$ of farmers have consumed underutilized crops for 4-6 meals $(25 \%$ of the food requirement) per week and $6.67 \%$ of farmers use underutilized crops for 7-9 meals $(40 \%$ of the food requirement) per week. The highest number of meals produced using underutilized crop was 10-12 per week and such amount of meals are consumed by $5 \%$ families of the area (52\% of the food requirement) per week (Table 02). These findings suggest that underutilized crops supply significant level of food to meet the food requirements of a family and also make these households food secure.

2. Extra income for the family.

Some farmers sell excess production of underutilized crops which remains after family consumption and earn an extra income. Especially, female farmers harvest excess production of underutilized crops at the end of the week and sell to the vendors who sell these produces in Sunday fairs. In addition, some of them process those underutilized crops as readyto-cook food and then sell. By making value added products, they can earn higher income. While majority of the farmers $(38 \%)$ earn in around LKR 2000 per week, another significant percentage of farmers $(25 \%)$ earn around LKR 1500 as shown in Table 03. Roughly this adds about LKR 6000 to 8000 to the monthly income, depending on the availability and seasonality of the crops. This amount is a significant addition for a household which lies closer to the vulnerable band of the poverty threshold line in these areas.

Table 02: Contribution of underutilized crops to the food requirement of the family $(n=120)$

\begin{tabular}{cccc}
\hline $\begin{array}{c}\text { Number of meals produced } \\
\text { Using UC( per week) }\end{array}$ & Frequency & Percentage & $\begin{array}{c}\text { Share of UUC the total food } \\
\text { requirement (per week) }\end{array}$ \\
\hline $1-3$ & 74 & $63.3 \%$ & $10 \%$ \\
$4-6$ & 32 & $25.0 \%$ & $25 \%$ \\
$7-9$ & 08 & $06.7 \%$ & $40 \%$ \\
$10-12$ & 06 & $05.0 \%$ & $52 \%$ \\
\hline
\end{tabular}

Source: Field survey, 2015

Table 03: Extra income for the family $(n=120)$

\begin{tabular}{ccc}
\hline Amount of income per week (LKR)* & Frequency & Percentage (\%) \\
\hline$<1000$ & 14 & 12 \\
$1001-1500$ & 30 & 25 \\
$1501-2000$ & 46 & 38 \\
$2001-2500$ & 19 & 16 \\
$>2500$ & 11 & 09 \\
\hline
\end{tabular}


3. Use of underutilized crops as herbals for simple health disorders.

Some underutilized crop species have many important medicinal properties beside their nutritional value. Instead of western medicine, rural people often use some underutilized crops as home based treatment for simple health disorders. Especially Bitter gourd (Momordica charantia L.), Thibbatu (Solanum torvum), Weralu (Elaeocarpus serratus), Ginger (Zingibe rofficinale), Tippili (Piper longum), Wadakaha (Acorus calamus), Kohila (Lasia spinosa) are used as traditional medicine. In this study, majority of the farmers (61\%) have used underutilized crops 1-2 times per week as herbals and $32 \%$ of farmers have used them 3-4 times per week as herbals. 5\% of farmers have used some underutilized crops 5-6 times per week as herbals. Also, $02 \%$ of farmers have used some of them more than 7 times per week. This information are presented in the Table 04. It is clear here that almost all the farmers used these crops as a source of medicine in varying forms. In addition to income, a tangible measure, medicinal values of underutilized crops are enormous that people even avoid consulting doctors, since these drugs are available through these crops. It saves the health expenditure of the poor households. Though it has not been tested, underutilized crops and their food serves as best sources of micro nutrients for the human body, saving many people from malnutrition and other diseases.

\section{Attitudes of farmers towards importance of cultivation of underutilized crops}

Assessment of the farmers' attitudes on cultivation and use of underutilized crops are very important for the development of these crops in future. Therefore, their attitudes towards the importance of the cultivation of underutilized crops were assessed using ten statements. The findings are given in the Table 05.

According to the findings, the farmers are strongly agree with the following three statements of the underutilized crops; 'Underutilized crops give economic benefits', 'Underutilized crops need low cost for cultivation', 'Underutilized crops need low level of water'. These farmers have lots of experience on cultivation of underutilized crops for a long time. They cultivate Finger millet (Eleusine coracana), Heen Meneri (Panicum sumatrense), Thanahal (Setaria italic), Gingili (Sesamum indicum) mainly as Chena cultivation with low amount of inputs.

Furthermore, farmers agreed with another four statements; 'Underutilized crops have nutritional values', 'Underutilized crops have medicinal values', 'Underutilized crops have less pests' and 'Underutilized crops have less diseases'. The farmers had very good understanding about different values of underutilized crops. They had received this knowledge from their parents and grandparents. However, Farmers neither agreed nor disagreed with three statements; 'Underutilized crops contribute for the biodiversity', 'Underutilized crops help for environment protection' and 'Underutilized crops can tolerate climate changes'. Even though few farmers were able to understand these broad concepts, most of the farmers have comparatively less educational level. So, they faced a difficulty to give a clear decision on these statements.

Table 04: Use as herbals for simple health disorders $(n=120)$

\begin{tabular}{ccc}
\hline Number of times per week & Frequency & Percentage (\%) \\
\hline $1-2$ & 73 & 61 \\
$3-4$ & 38 & 32 \\
$5-6$ & 06 & 05 \\
$>7$ & 03 & 02 \\
\hline
\end{tabular}

Source: Field survey, 2015 
Table 05: Attitudes of farmers towards importance of cultivation of underutilized crops $(n=120)$

\begin{tabular}{ccccc}
\hline Attitudinal statement & $\begin{array}{c}\text { Mean } \\
\text { Value }\end{array}$ & $\begin{array}{c}\text { Standard } \\
\text { Deviation }\end{array}$ & Median & Remarks \\
\hline Underutilized crops give economic benefits & 1.6333 & 0.4839 & 2.0000 & Strongly Agree \\
Underutilized crops have nutritional values & 1.3833 & 0.6882 & 1.5000 & Agree \\
Underutilized crops have medicinal values & 1.4167 & 0.7400 & 2.0000 & Agree \\
Underutilized crops need low cost for cultivation & 1.8167 & 0.3886 & 2.0000 & Strongly Agree \\
Underutilized crops need low level of water & 1.7500 & 0.4719 & 2.0000 & Strongly Agree \\
Underutilized crops have less pests & 1.4833 & 0.5018 & 1.0000 & Agree \\
Underutilized crops have less diseases & 1.4333 & 0.6447 & 2.0000 & Agree \\
Underutilized crops contribute for the biodiversity & 0.4500 & 0.6463 & 1.0000 & Neutral \\
Underutilized crops help for environment protection & 0.383 & 1.175 & 1.0000 & Neutral \\
Underutilized crops can tolerate climate changes & 0.4167 & 0.5589 & 0.0000 & Neutral \\
\hline
\end{tabular}

Source: Field survey, 2015

\section{CONCLUSION}

Although it is not generally seen, a large number of underutilized crops are being cultivated by rural farmers in this district. Among them, cereals, vegetables, legumes, oil crops, root and tuber crops, fruit crops and herbal crops are very common. They cultivate these crops in smallscale mainly for their own consumption. Due to lack of demand and low price in the market for these crops, they cultivate other commercial crops to earn living.

Most of the farmers have general knowledge about the importance of underutilized crops. Main goals of cultivation of underutilized crops are to fulfill the food requirement of the family, especially they provide food security for the family), find extra income for the family and to use them as herbals for simple health disorders of family members and neighbors. They have gained that knowledge from their parents and grandparents. Underutilized crops were the main source of living of their ancestors. Ancestors had used these crops to get balance diet, get rid of diseases, to cure injuries, snake bites and other accidents. In the past, these crops were grown in almost all the houses. Owing to that, these farmers also have sufficient level of knowledge about cultivation and management of these crops.
However, their understanding about the broad level of importance is at a low level. This is a rural area and most of these farmers have only completed their primary level of education. Although a few farmers have general understanding about the concepts like biodiversity, environmental protection, and climatic change the majority do not have a sufficient knowledge to understand them.

As per the findings of the group discussion, it is worth to note that the farmers are still willing to cultivate these crops for selling if they can have necessary facilities. Therefore, it is important to make arrangements to develop and popularize these crops among the people. Provision of marketing facilities, necessary inputs, storage and processing facilities will help them to keep on growing these crops in their own farms.

\section{RECOMMENDATIONS}

According to the findings, the development of cultivation of underutilized crops can be done through,

- $\quad$ Supplying inputs needed and motivating farmers to grow these crops.

Organizing extension and awareness 
programs to improve farmers' knowledge and necessary skills on these crops.

- $\quad$ Facilitating farmers with good storage, processing and marketing facilities.

- Launching proper research and development programs to improve these crops.

- Effective policy frameworks to popularize these crops among city dwellers.

\section{ACKNOWLEDGEMENT}

This research was conducted under a university research grant of Sabaragamuwa University of Sri Lanka. The author acknowledges the vice chancellor and the research grant committee for giving financial support to carry out this research study.

\section{REFERENCES}

Bandula, A., Jayaweera, C., De Silva, A., Oreiley, P., Karunarathne, A. and Malkanthi, S. H. P. (2016). Role of Underutilized Crop Value Chains in Rural Food and Income Security in Sri Lanka. Procedia Food Science, 6: 267-270. DOI: http://dx.doi.org/10.1016/j.profoo.2016.02.049

Chandrarathne, R. (2007). Under-utilized crops and fight against hunger and poverty. Sunday Observer, $6^{\text {th }}$ May 2007. DOI: http://dx.doi.org/10.1057/9781137491213.0008

Chivenge, P., Mabhaudhi, T., Modi, A.T. and Mafongoya, P., (2015). The potential role of neglected and underutilized crop species as future crops under water scarce conditions in Sub-Saharan Africa. International Journal of Environmental Research and Public Health, 12(6): 56855711. DOI: http://dx.doi.org/10.3390/ijerph120605685

Hoeschle, I., Zeledon, and Jaenicke, H. (2009). A strategic framework for research and development of underutilized plant species with special reference to Asia, the pacific and sub Saharan Africa. DOI: http://dx.doi.org/10.17660/actahortic.2009.818.49

Hoeschle-Zeledon, I. and Bordoni, P. (2003). Approaches and decision steps for the promotion and development of underutilized plant species. Global facilitation unit for Underutilized species. Rome, Italy. DOI: http://dx.doi.org/10.1079/9781845930998.0605

Kole, C. ed., (2011). Genetics, genomics and breeding of cool season grain legumes. E-Book, Science Publishers. DOI: http://dx.doi.org/10.1017/s0014479712000257

Malkanthi, S.H.P, Karunaratne, A.S., Amuwala, S.D. and Silva, P., (2014). Opportunities and Challenges in Cultivating Underutilized Field Crops in Moneragala District of Sri Lanka. Asian Journal of Agriculture and rural Development, 4(1): 96-105. DOI: http:// dx.doi.org/10.1504/ijarge.2016.074680

Mayes, S., F.J.Massawe, P.G.Alderson, J.A.Roberts, S.N.Azam-Ali, and M .Hermann. (2011). The potential for underutilized crops to improve security of food production. Experimental Botany, 63 (3): 1075-1079. DOI: http://dx.doi.org/10.1093/jxb/err396

Padulosi, S. and Frison, E. (1999). The role of underutilized plant species in the 21 st Century, Washington D.C, USA. DOI: http://dx.doi.org/10.1079/9780851995229.0323 
Padulosi, S. P., Eyzaquirre, and Hodgkin, T. (1999). Challenges and strategies in promoting conservation and use of neglected and underutilized crop species. ASHS Press, Alexandria,VA. DOI: http://dx.doi.org/10.1079/9781845930998.0605

Taylor, M., Jaenicke, H., Skelton, P., and Mathur, P. N. (2009). Regional Consultation on Crops for the Future: Towards Food, Nutritional, Economic and Environmental Security in the Pacific, National Agricultural Research Institute. DOI: http://dx.doi.org/10.17660/ actahortic.2011.918.49

Williams, J. T. and Haq N. (2010).Underutilized Crops for Food Security and Poverty Alleviation, ICUC. University of Southampton, Southampton SO17 1BJ, UK. DOI: http://dx.doi. org/10.1895/wormbook.1.143.2

Williams, J. T. and Haq, N. (2000). Global research on underutilized crops an assessment of current activities and proposals for enhanced cooperation. International Centre for Underutilized Crops. DOI: http://dx.doi.org/10.1079/9780851995229.0323

Williams, J.T. and Haq, N., (2002). Global research on underutilized crops. An assessment of current activities and proposal for enhanced cooperation. International Centre for Underutilized Crops, University of Southampton, United Kingdom. DOI: http://dx.doi.org/10.17660/ actahortic.2013.979 